\title{
Effect of gossypol on survival and reproduction of the zoophytophagous stinkbug Podisus nigrispinus (Dallas)
}

\author{
Walter S. Evangelista Junior ${ }^{1}$, Roberta L. Santos², Jorge B. Torres ${ }^{2,3} \&$ José C. Zanuncio $^{4}$
}

\author{
${ }^{1}$ Universidade Federal do Pará, Colegiado de Ciências Agrárias, Quadra 04, 68501-970 Maraba-PA, Brazil. wevangelista@ufpa.br \\ ${ }^{2}$ Departamento de Agronomia-Entomologia, Universidade Federal Rural de Pernambuco, Rua Dom Manoel de Medeiros s/n, Dois Irmãos, \\ 52171-900 Recife-PE, Brazil. robertaleme2@uol.com.br, jtorres@depa.ufrpe.br \\ ${ }^{3}$ Corresponding author: jtorres@depa.ufrpe.br \\ ${ }^{4}$ Departamento de Biologia Animal, Universidade Federal de Viçosa, 36571-000 Viçosa-MG, Brazil. zanuncio@ufv.br
}

\begin{abstract}
Effect of gossypol on survival and reproduction of the zoophytophagous stinkbug Podisus nigrispinus (Dallas). Gossypol is a sesquiterpene aldehyde found in cotton plants conferring resistance against herbivory. Although the effect of this sesquiterpenoid on insect pests of cotton is known, the interaction of this compound with zoophytophagous predators such as Podisus nigrispinus (Dallas) (Hemiptera, Pentatomidae) has not been studied so far. Thus, the objective of this study was to evaluate the effect of the purified gossypol on nymphs and adults of P. nigrispinus. Nymphs and adults of this predator were fed on Tenebrio molitor pupae and supplemented with solutions of gossypol at concentrations of $0.00,0.05,0.10$, and $0.20 \%$ (w/v) during the nymphal and adult stages or, only during the adult stage of P. nigrispinus. The nymphal stage of the predator was, on average, two days longer when suplemmented with gossypol. Emerged adults had lower fecundity and egg hatching, especially at the highest gossypol concentration $(0.20 \%)$ ingested during the nymphal and adult stages. However, this predator was not affected when it ingested the compound only during the adult stage. P. nigrispinus can have delayed nymphal development and lower reproductive performance when ingesting the gossypol during the nymphal and adult stages, but only at higher concentrations of gossypol than that produced by cotton plants.
\end{abstract}

\begin{abstract}
KEYWORDS. Asopinae; host plant resistance; omnivory; zoophytophagy.
RESUMO. Efeito do gossipol na sobrevivência e reprodução do percevejo zoofitófago Podisus nigrispinus (Dallas). O gossipol é um aldeído sesquiterpeno produzido pelo algodoeiro que confere resistência contra a herbivoria. A interação deste sesquiterpeno com predadores zoofitófagos, como Podisus nigrispinus (Dallas) (Hemiptera, Pentatomidae), é inexistente apesar do reconhecido efeito do gossipol sobre insetos pragas do algodoeiro. Assim, este estudo avaliou o efeito do extrato de gossipol sobre ninfas e adultos de P. nigrispinus. O predador foi alimentado com pupas de Tenebrio molitor L. (Coleoptera, Tenebrionidae) e suplementado com soluções do gossipol nas concentrações $0,0,05,0,10$ e $0,20 \%$ (peso/volume) durante os estágios ninfal e adulto e somente durante o estágio adulto. A duração do estágio ninfal do predador foi em média dois dias mais longo quando suplementado com gossipol. Adultos oriundos de ninfas suplementadas com gossipol apresentaram menor fecundidade e viabilidade dos ovos, em especial na maior concentração $(0,20 \%)$. Contudo, adultos não foram afetados quando suplementados com gossipol somente durante este estágio. Os resultados demonstram que a ingestão prolongada do gossipol ocasiona efeito no desenvolvimento e reprodução do predador P. nigrispinus, porém somente em concentração superior àquela produzida naturalmente pela planta de algodão.
\end{abstract}

PALAVRAS-CHAVE. Asopinae; onivoria; resistência de plantas; zoofitofagia.

The allelochemical gossypol is a sesquiterpenoid phenol aldehyde with variable concentrations in the leaves depending on the cotton [Gossypium hirsutum L. (Malvaceae)] variety and other cotton plant parts with glandular predisposition for this compound (Rudgers et al. 2004; Younis \& Darrag 2007). The properties of gossypol include reduction of the digestibility in herbivores (Elsebae et al. 1981), representing a resistance factor by antibiosis to chewing and sucking cotton pests (Syed et al. 2003; Du et al. 2004). Cotton plants with high gossypol levels are resistant by antibiosis or non preference to Aphididae, Miridae, Tetranychidae, Thripidae, and caterpillars, especially Heliothis and Helicoverpa larvae (Noctuidae) (Gannaway 1994; Stipanovic et al. 2006). Furthermore, abundance of insect pests in cotton fields cultivated with varieties with gossypol shows that this compound acts as a defense mechanism against herbivory (Syed et al. 2003; Leghari et al. 2001).

The effect of gossypol on herbivorous species of cotton is well-known; however, the interaction of gossypol with natural enemies of herbivorous is poorly known. Gossypol can have direct and indirect effects on these natural enemies. Direct contact of zoophytophagous predatory species with gossypol might take place when predators feed on plants. Predatory stinkbugs, such as Podisus nigrispinus (Dallas) (Hemiptera, Pentatomidae) usually feed on host plants of their prey independent of the satiation level (Evangelista Junior et al. 2004; Coelho et al. 2008). On cotton plants this predatory stinkbug feeds on apoplastic spaces and xylem (Torres et al. 2010) and ingests considerable amount of plant material which corresponds to approximately $28 \%$ and $30 \%$ of their body weight 
(Coelho et al. 2009). Indirect contact with gossypol produced by plants might also occur when predators consume contaminated herbivore prey fed on cotton with high levels of gossypol. Gossypol had negative effect on Campoletis sonorensis (Cameron) (Hymenoptera, Ichneumonidae) parasitizing Heliothis virescens (Lepidoptera, Noctuidae) reared on cotton cultivars with high levels of gossypol (Gunasena et al. 1989). On the other hand, the biological traits of Propylaea japonica (Thunberg) (Coleoptera, Coccinellidae) were similar when preying on Aphis gossypii Glover (Hemiptera, Aphididiae) fed on the cotton variety M9101 with high gossypol levels in relation to ZMZ13 and HZ401 with low and medium gossypol levels, respectively (Du et al. 2004).

The combination of plant resistance and biological control measures is essential for the success of any integrated pest management program. A series of studies after Campbell \& Duffey (1979), however, has demonstrated that secondary compounds conferring resistance against herbivores sometimes result in negative effects on their natural enemies (Bottrell et al. 1998; Coley et al. 2006). Furthermore, herbivores have coevolved with host plant defense mediated by the detoxification of the secondary compounds becoming specialized and, hence, using of the secondary compounds as a second hand defense against their own predators and parasitoids (Nishida 2002; Coley et al. 2006). However, specialized plant defense has a larger impact on generalist predators when interacting with their herbivore prey living on plants expressing secondary compounds for resistance (Traugott \& Stamp 1997; Francis et al. 2000; Vivan et al. 2003). The predatory stinkbug $P$. nigrispinus preys on a large variety of defoliating insects (Torres et al. 2006). Moreover, this predator, also displays plant feeding behavior, thus creating direct exposure pathways of interaction with possible poisonous effects of the gossypol directly by feeding on plants and indirectly by preying on contaminated insects that ingested the gossypol from cotton plants. In fact, plant feeding by $P$. nigrispinus implies direct contact with toxicants in cotton plant vessels (Torres et al. 2003; Torres \& Ruberson 2004; Torres et al. 2010). Thus, in this study we investigated the hypothesis that the gossypol, a compound offerring cotton plant resistance against herbivores through reducing digestibility, affects the development and reproduction of zoophytophagous predators. To ascertain about this hypothesis the effect of direct ingestion of the gossypol for long periods by $P$. nigrispinus were performed. The experiments were set up to allow the continuous ingestion of gossypol by nymphs and adults or only through the exposure during the adult stage.

\section{MATERIAL AND METHODS}

The effect of the ingestion of gossypol on the development, survival and reproduction of the predator P. nigrispinus was investigated in two experiments: long-term ingestion during the nymphal and adult stages (i); and only during the adult stage (ii). The purified gossypol was obtained from Embrapa Algodão, Campina Grande, in the State of Paraíba, Brazil.
Ingestion of gossypol during nymphal and adult stages. The experiment was carried out at the Laboratory of Biological Control of Insects of the Universidade Federal Rural de Pernambuco (UFRPE) in Recife, state of Pernambuco, Brazil. Sixty nymphs of the predator, at the beginning of second instar $(<24$ hours) since the first instar does not feed on prey, were separated in groups of six per Petri dish ( $15 \mathrm{~cm}$ diameter and $1.2 \mathrm{~cm}$ height) at $25 \pm 1{ }^{\circ} \mathrm{C}, 71 \pm 10 \% \mathrm{RH}$ and photoperiod of 12 hours. These nymphs were continuously exposed to the gossypol through ingestion during the nymphal and adult stages by offering solutions of gossypol at concentrations of 0.05 , 0.10 or $0.20 \%$, and $0 \%$. The solutions were offered to the nymphs in $1.5 \mathrm{~cm}^{3}$ plastic tubes fastened to the superior internal part of the Petri dish covers used to rear the nymphs. Later these tubes were fixed to the cover of the $500 \mathrm{~mL}$ plastic containers used to rear the adults of $P$. nigrispinus. Predators in all treatments (gossypol concentrations and water control) were fed with Tenebrio molitor L. (Coleoptera, Tenebrionidae) pupae. The duration and mortality of nymphs and emergence and mortality of adults $P$. nigrispinus were monitored.

Adults of $P$. nigrispinus were separated by sex and maintained individually during three days during the pre-reproductive period (Carvalho et al. 1995). After this period, predators were paired in $50 \mathrm{~mL}$ plastic containers with 10 pairs per treatment and each pair represented a replication. The gossypol solution and T. molitor pupae were substituted every two days during the adult stage. During food replacement, the egg masses were collected and the mortality of females was also recorded. The duration and survival of the nymphal period, the longevity of females and egg and nymph production of this predator were obtained.

Ingestion of gossypol during adult stage. In the second experiment the gossypol solution was offered only during the adult stage of $P$. nigrispinus to exclude the possible effect of the gossypol on the developmental stage. Newly emerged adults of $P$. nigrispinus were obtained from the rearing facility of the Laboratory of Biological Control of UFRPE. The adults were weighed to select females between 50 and $70 \mathrm{mg}$ and males between 30 and $50 \mathrm{mg}$, which were randomly assigned to receive one of the following treatments: control (water) or the gossypol concentrations of $0.05,0.10$ and $0.20 \%$. The solutions of gossypol were continuously offered to the predator and the replacement of the solution was every other day, as done in the previous experiment. Egg masses were collected and maintained in Petri dishes with moistened cotton pad to evaluate egg hatching.

Statistical analysis. To determine whether the predator responded positively or negatively to the ingestion of different gossypol concentrations compared to the water as the control treatment, the results were subjected to analysis of regression. The analsys was conducted using the Proc REG of SAS (SAS Institute 2001) considering the duration and the viability of the nymphal stage, pre-oviposition period, number of eggs, and the proportion of egg hatching as the dependent variables (y) as a function of gossypol concentrations as the independent variables (x). The fitted models were 
selected based on significance of the coefficients $(\mathrm{P}<0.05)$ and their contribution to the best biological representation. The proportions of live females along the adult stage, starting from 10 females per treatment (control and gossypol concentrations) were used to estimate the survival curves of predator fed gossypol solution and the control using the Kaplan-Meier method through Proc LIFETEST of the SAS and the test of Long-Rank to compare survival means (SAS Institute 2001).

\section{RESULTS AND DISCUSSION}

The nymphs of $P$. nigrispinus supplemented with gossypol experienced significant delay in the development, which ranged from 20.3 to 20.7 days compared to nymphs from control treatment ( $0 \%$ gossypol, $18.2 \pm 0.37$ days) disregarded the gossypol concentrations (Fig. 1). Delayed nymphal development of $P$. nigrispinus fed on gossypol concentrations $(0.05,0.10$ and $0.20 \%)$ indicates negative effect of this sesquiterpenoid on this predator and that these effects do not seem to depend on the amount of product ingested. The effect of gossypol ingestion was not related with the concentrations used because nymphal development of the predator was similar among the concentrations from 0.05 to $0.20 \%$. Since gossypol is, in general, a reducer of digestibility (Meisner et al. 1978; Elsebae et al. 1981; Stipanovic et al. 2006), the effect may not depend on the concentration used and the common result is related to lower development, weight and fecundity.

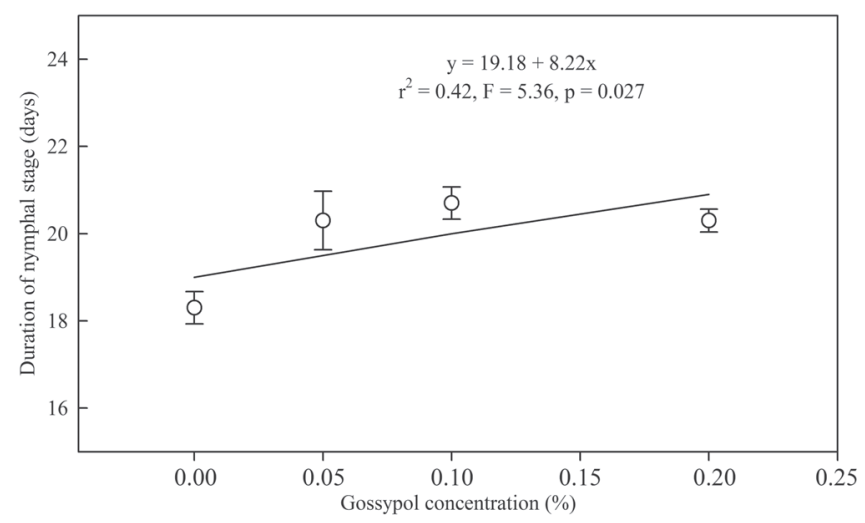

Fig. 1. Duration of nymphal stage for Podisus nigrispinus fed Tenebrio molitor pupae and supplemented with different concentrations of gossypol.

Females of $P$. nigrispinus from nymphs fed on T. molitor pupae and receiving continuous gossypol during the nymphal and adult stages exhibited similar pre-oviposition period $\left(\mathrm{F}_{\mathrm{df}=1,42}=0.29, \mathrm{P}=0.594\right)$ with values from 6.4 to 7.2 days. However, egg production was significantly affected according to the concentration of gossypol offered to the female $\left(\mathrm{F}_{\mathrm{df}=1,42}=9.94, \mathrm{P}=0.003\right)$ (Fig. 2A). Females from control treatment ( $0 \%$ gossypol) produced, on average, 452 eggs, whereas those supplemented with the concentrations of 0.05 ,
0.10 and $0.20 \%$ gossypol produced, on average, 423,305 and 244 eggs, respectively. Egg hatching was also reduced $\left(\mathrm{F}_{\mathrm{df}=3,42}=11.73, \mathrm{P}=0.001\right)$, for those females fed on the highest gossypol concentration (i.e., $51.4 \%$ versus $75 \%$ ) (Fig. 2B). However, females exposed to gossypol only during the adult stage exhibited similar pre-oviposition periods $\left(\mathrm{F}_{\mathrm{df}=1,39}=0.01, \mathrm{P}=0.971\right)$, mean number of eggs per female $\left(\mathrm{F}_{\mathrm{df}=1,39}=1.71, \mathrm{P}=0.199\right)$ and egg hatching proportion $\left(\mathrm{F}_{\mathrm{df}=1,39}=0.11, \mathrm{P}=0.962\right)$. The pre-oviposition period and the number of eggs per female varied from 4.2 to 5.4 days and from 248.5 to 369.9 eggs, and egg hatching from 68 to $75 \%$, respectively (Fig. $2 \mathrm{~B}$ ).
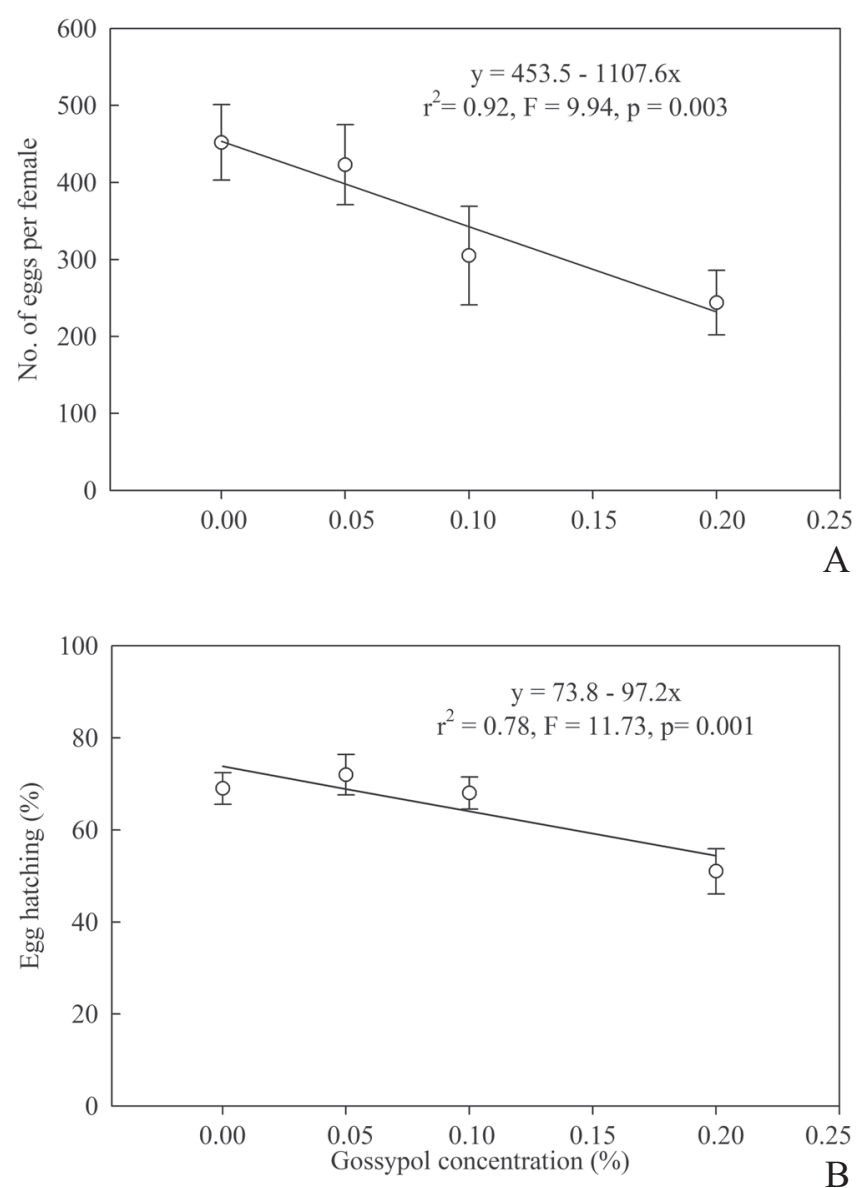

Fig. 2. (A) Number of eggs produced, and (B) the proportion of egg hatching for Podisus nigrispinus fed Tenebrio molitor pupae and supplemented or not $(0 \%)$ with different concentrations of gossypol during the nymphal and adult stage or only during the adult stage. Symbols stand for mean \pm standard error.

Nymphal survivorship of $P$. nigrispinus supplemented continuously with gossypol under different concentrations was similar $\left(\mathrm{F}_{\mathrm{df}=1,42}=2.91, \mathrm{P}=0.095\right)$ including the control and, with values from 86.1 to $96.6 \%$ survival. However, females fed gossypol since nymphal stage exhibited survival values variable among treatments in the adult stage (Test of Log-Rank, df $=3, \chi^{2}=10.92, P=0.0122$ ) (Fig. 3B) with 
mean longevity ranging from 26.0 to 49.7 days, and higher values for females exposed to the highest concentration of gossypol. Female P. nigrispinus fed on gossypol only during the adult stage had similar survival (Test of Log-Rank, $\mathrm{df}=3$, $\chi^{2}=0.74, \mathrm{P}=0.8631$ ) (Fig. $3 \mathrm{~A}$ ), with similar longevity ranging from 39.2 to 48.5 days.

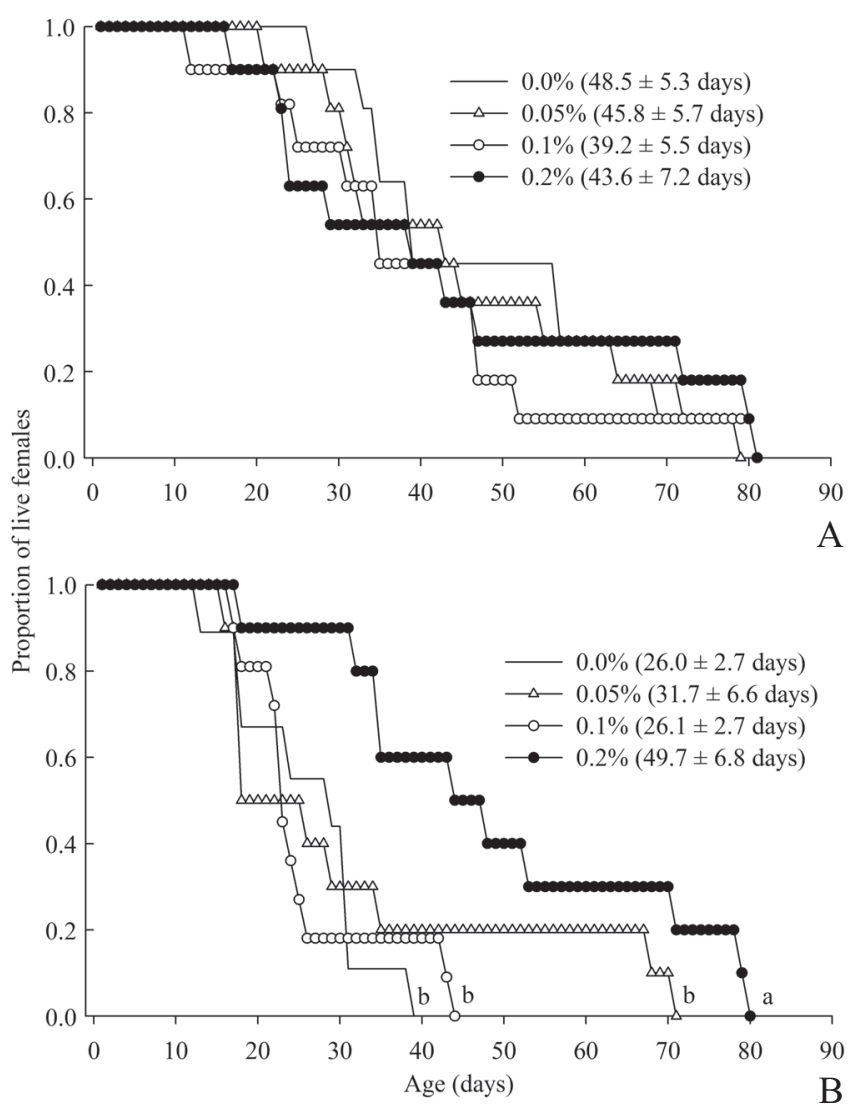

Fig. 3. Age-specific survivorship for Podisus nigrispinus females fed Tenebrio molitor pupae and supplemented or not (0\%) with gossypol in different concentrations during the adult stage (a) or continually in the nymphal and adult stages (A). Different letters in B stand for pairwise comparisons of the survival curves for concentrations by Log Rank Test at $0.05 \%$ level of significance. Values between parentheses stand for means of longevity \pm standard error.

The lowest fecundity and egg viability results for $P$. nigrispinus females reared continuously supplemented with gossypol at $0.2 \%$ confirms the hypothesis that this compound offers resistance against herbivores through reducing digestibility and has potential to affect a predator ingesting it. Thus, the accumulative effect reduces development of insects and, consequently, reproduction (Elsebae et al. 1981). However, the similar fecundity and egg hatching for females of this predator exposed to gossypol only in the adult stage indicate a negative effect of this compound only if ingested during the nymphal stage. The direct relation between lower fecundity (Fig. 2A) and higher survival (Fig. 3B) for females continuously exposed to $0.2 \%$ of gossypol indicates an effect of this compound at higher concentration through phagodeterrence (Meisner et al. 1977). In addition, the prey ingested results in lower assimilation of food. The use of prey might have been lower, because this compound affects the digestibility, resulting in a situation of reduced food assimilation (Meisner et al. 1977; Legaspi \& O’Neil 1994). The trade-off between higher survival and lower fecundity is a common finding for P. nigrispinus (Molina-Rugama et al. 1997; Oliveira et al. 2002), and for other predators under prey scarcity (Torres et al. 2004). Gossypol at the higher concentrations might reduce food absorption thereby limiting nutrients and causes the predator to relocate energy from reproduction to survival.

Gossypol reduced the development and, hence, delayed the period for $P$. nigrispinus to complete its nymphal stage and reproduction, but with minimum or no effect on survival. This result is typical of digestibility reducers on Asopinae predators (Ashouri et al. 1998; Bell et al. 2003). Digestibility reducing compounds usually cause sublethal effects by interferring with the development and reproduction of these organisms, similar to what was found for the development and reproduction of $P$. nigrispinus.

The adverse effects found on the development of $P$. nigrispinus nymphs characterize impact of continuous ingestion of gossypol. Conversely, the indirect exposure of this predator through the prey Alabama argillacea (Hüebner) (Lepidoptera, Noctuidae) reared on cotton cultivar with high levels of gossypol, demonstrated the absence of the effect on this predator (Santos \& Boiça-Junior 2002). Furthermore, caging $P$. nigrispinus on the cotton genotype "XG 15 " producing high levels of gossypol showed no negative effect on the predator development and reproduction (W.S.E. Jr. unpublished data). Thus, despite the sublethal effect of gossypol on this zoophytophagous insect as evidenced in this study, the negative interaction of cotton varieties expressing gossypol can be minimized by the plant feeding habit of $P$. nigrispinus. This predator feeds on apoplastic spaces and xylem structures of the plant and, likely, avoinding the gossypol producing glands (Torres et al. 2010). The adverse effects of gossypol on development and reproduction of $P$. nigrispinus found in this study characterize the worst possible scenario of contamination. In the field, feeding on prey or directly on the plant, P. nigrispinus is likely to be exposed to negligible concentrations of gossypol. This agrees with the results found in this study when offering gossypol at lower concentrations or when the predators were exposed to the gossypol only during the adult stage only.

Resistance of cotton plants based on gossypol levels is promising against generalist herbivore species, but do not provide a full control (Stipanovic et al. 2006). Furthermore, specialized cotton pest species as the leaf feeding caterpillars are not affected by the level of gossypol naturally produced in commercial cotton due to co-evolvotion with the host plant defense (Nishida 2002). Therefore, the additional mortality caused by natural enemies such as $P$. nigrispinus are important within the pest management approach of cotton pests. 


\section{ACKNOWLEDGEMENTS}

This research was sponsored by CAPES, CNPq, and FACEPE.

\section{REFERENCES}

Ashouri A.; D. Overney; C. Michaud \& I. Cloutier, I. 1998. Fitness and feeding are affected in the two-spotted stinkbug, Perillus bioculatus, by the cysteine proteinase inhibitor, oryzacystatin I. Archives of Insect Biochemistry and Physiology 38: 74-83.

Bell, H. E.; R. E. Down; E. C. Fitches; J. E. Edwards \& A. M. R. Gatehouse. 2003. Impact of genetically modified potato expressing plant-derived insect resistance genes on the predatory bug Podisus maculiventris (Heteroptera: Pentatomidae). Biocontrol Science and Technology 13: 729-741.

Bottrell, D. G.; P. Barbosa \& F. Gould. 1998. Manipulating natural enemies by plant variety selection and modification: a realistic strategy? Annual Review of Entomology 43: 347-367.

Campbell, B. C. \& S. S. Dufey. 1979. Tomatine and parasitic wasps: potential incompatibility of plant antibiosis with biological control. Science 205: $700-702$.

Carvalho, R. D. S.; E. F. Vilela; M. Borges \& J. C. Zanuncio. 1995. Comportamento de acasalamento do predador Podisus nigrispinus (Dallas), em laboratório. Anais da Sociedade Entomológica do Brasil 24: 165-171.

Coelho, R. R.; J. M. Araujo Junior \& J. B. Torres. 2008. Comportamento de predação de Podisus nigrispinus (Dallas, 1851) (Hemiptera: Pentatomidae) em função da disponibilidade de alimento. Arquivos do Instituto Biológico 75: 463-470.

Coelho, R. R.; A. F. S. L. Veiga \& J. B. Torres. 2009. Preferência alimentar e desempenho de Brontocoris tabidus Signoret (Hemiptera, Pentatomidae) em plantas hospedeiras. Revista Brasileira de Entomologia 53: 475-481.

Coley, P. D.; M. L. Bateman \& T. A. Kursar. 2006. The effects of plant quality on caterpillar growth and defense against natural enemies. Oikos 115: 219-228.

Du, L.; F. Ge; S. Zhu \& M. N. Parajulee. 2004. Effect of the cotton cultivar on development and reproduction of Aphis gossypii (Homoptera: Aphididae) and its predator Propylaea japonica (Coleoptera: Coccinellidae). Journal of Economic Entomology 97: 1278-1283.

Elsebae, A. H.; S. I. Sherby \& N. A. Mansour. 1981. Gossypol as an inducer or inhibitor in Spodoptera littoralis larvae. Journal of Environmental Science and Health B 16: 167-178.

Evangelista Junior, W. S.; M. G. C. Gondim Jr; J. B. Torres \& E. J. Marques. 2004. Fitofagia de Podisus nigrispinus em algodoeiro e plantas daninhas. Pesquisa Agropecuária Brasileira 39: 413-420.

Francis, F.; E. Haubruge \& C. Gaspar. 2000. Influence of host plants on specialist/ generalist aphids and on the development of Adalia bipunctata (Coleoptera: Coccinellidae). European Journal of Entomology 97: 481-485.

Gannaway, J. R. 1994. Breeding for insect resistance, p. 431-453. In: G. A. Matthews\& J. P. Tunstall (eds.). Insect pests of cotton. Willingford, CAB International, $593 \mathrm{p}$.

Gunasena, G. H.; S. B. Vinson; H. J. Williams \& R. D. Stipanovic. 1989. Development and survival of the endoparasitoid Campoletis sonorensis (Hymenoptera: Ichneumonidae) reared from gossypol exposed Heliothis virescens (F.) (Lepidoptera: Noctuidae). Environmental Entomology 18: 886-891.

Legaspi, J. C. \& R. J. O’Neil. 1994. Developmental response of nymphs of Podisus maculiventris (Heteroptera: Pentatomidae) reared with low numbers of prey. Environmental Entomology 23: 374-380.

Leghari, M. A.; A. M. Kalroo \& A. B. Leghari. 2001. Studies on host plant resistance to evaluate the tolerance/susceptibility against cotton pests.
Pakistan Journal of Biological Science 4: 1506-1508.

Meisner, J.; K. R. S. Ascher \& M. Zur. 1977. Phagodeterrency induced by pure gossypol and leaf extracts of a cotton strain with high gossypol content in the larva of Spodoptera littoralis. Journal of Economic Entomology 70: 149-150.

Meisner, J.; I. Ishaaya; K. R. S. Ascher \& M. Zur. 1978. Gossypol inhibits protease and amylase activity of Spodoptera littoralis larvae. Annals of the Entomological Society of America 71: 5-8.

Molina-Rugama, A. J.; J. C. Zanuncio; J. B. Torres \& T. V. Zanuncio. 1997. Longevidad y fecundidad de Podisus nigrispinus (Heteroptera: Pentatomidae) alimentado con Musca domestica (Diptera: Muscidae) y frijol. Revista de Biologia Tropical 45: 1125-1130.

Nishida, R. 2002. Sequestration of defensive substances from plant by Lepidoptera. Annual Review of Entomology 47: 57-92.

Oliveira, J. E. M.; J. B. Torres; A. F. Carrano-Moreira \& J. C. Zanuncio. 2002. Biologia de Podisus nigrispinus predando lagartas de Alabama argillacea em campo. Pesquisa Agropecuária Brasileira 37: 7-14.

Rudgers, J. A.; S. Y. Strauss \& J. F. Wendel. 2004. Trade-offs among antiherbivore resistance traits: insights from Gossypieae (Malvaceae). American Journal of Botany 91: 871-880.

Santos, T.M. \& A. L. Boiça-Júnior. 2002. Biological aspects and predatory capacity of Podisus nigrispinus (Dallas) (Hemiptera: Pentatomidae) fed on Alabama argillacea (Hubner) (Lepidoptera: Noctuidae) reared on cotton genotypes. Scientia Agricola 59: 671-675.

SAS Institute. 2001. SAS/STAT User's guide, version 8.02, TS level 2MO. SAS Institute Inc

Stipanovic, R. D.; J. D. Lopez-Junior; M. K. Dowd; L. S. Puckhaber \& S. E. Duke. 2006. Effect of racemic and $(+)$ and $(-)$ gossypol on the survival and development of Helicoverpa zea larvae. Journal of Chemical Ecology 32: 959-968.

Syed, T. S.; G. H. Abro, R. D. Khuhro \& M. H. Dhauroo. 2003. Relative resistance of cotton varieties against sucking pests. Pakistan Journal of Biological Science 6: 1232-1233.

Torres, J. B. \& J. R. Ruberson. 2004. Toxicity of thiamethoxam and imidacloprid to Podisus nigrispinus (Dallas) (Heteroptera: Pentatomidae) nymphs associated to aphid and whitefly control in cotton. Neotropical Entomology 33: 99-106.

Torres, J. B.; C. S. A. Silva-Torres \& R. Barros. 2003. Relative effect of the insecticide thiamethoxam on the predator Podisus nigrispinus and the tobacco whitefly Bemisia tabaci in nectaried and nectariless cotton. Pest Management Science 59: 315-323.

Torres, J. B.; C. A. Silva-Torres; J. R. Ruberson. 2004. Effect of two prey types on life-history characteristics and predation rate of Geocoris floridanus (Heteroptera: Geocoridae). Environmental Entomology 33: 964-974.

Torres, J. B.; J. C. Zanuncio \& M. A. Moura. 2006. The predatory stinkbug Podisus nigrispinus: biology, ecology and augmentative releases for lepidopteran larval control in Eucalyptus in Brazil. CAB Reviews: Perspectives in Agriculture, Veterinary Science, Nutrition and Natural Resources 1: 1-18.

Torres, J. B.; E. M. Barros; R. R. Coelho \& R. M. M. Pimentel. 2010. Zoophytophagous pentatomids feeding on plants and implications for biological control. Arthropod-Plant Interactions 4: 219-227.

Traugott, M. S. \& N. E. Stamp. 1997. Effects of chlorogenic acid- and tomatine-fed caterpillars on performance of an insect predator. Oecologia 109: 265-272.

Younis, H. M. \& H. Darrag. 2007. Terpenoid aldehydes in Egyptian cotton cultivars. FASEB Journal 21: 999-1000.

Vivan, L. M.; J. B. Torres; A. F. S. L. Veiga. 2003. Development and reproduction of a predatory stinkbug, Podisus nigrispinus, in relation to two different prey types and environmental conditions. BioControl 48: $155-168$. 